Ritrýnd grein birt 31. desember 2018

\title{
Hjartað, kjarni mennsku og menntunar?
}

\author{
Jón Ásgeir Kalmansson
}

\begin{abstract}
Um höfundinn About the author $\quad$ Heimildir
Í greininni er sjónum beint að heimspekilegri orðræðu um hjartað og grafist fyrir um merkingu og mikilvægi pessa hugtaks í siðfræðilegu samhengi. Fyrst er rætt um hjartað í ljósi hefðarinnar og upprunalegs skilnings á heimspeki sem viskuást. Pá eru tengsl hjartans við eigingildi skoðuð, pað er hjartað er sett í samhengi við skilning á gildi hlutanna í sjálfu sér. Dví næst er athyglinni beint að sambandi hjartans og mannlegs særanleika og berskjöldunar. Gerð er grein fyrir peirri hugmynd að hjartað, í mynd líkamlegs, félagslegs og andlegs særanleika, sé kjarni mennskunnar og hins mannlega eiginleika að vera opinn fyrir veröldinni. Hjartað er pá jafnframt skilið sem aðsetur pess hæfileika mannssálarinnar að geta orðið fyrir sterkum áhrifum eða djúpt snortin af pví sem hún kemst í snertingu við. Að pví loknu verður varpað nokkru ljósi á hjartað sem skynjun eða innsæi, og sú pýðing hugtaksins tengd sérstaklega við hugtök á borð við ímyndunarafl og ást. Pá er vikið að tengslum hugtaksins við frumspekilegan skilning fólks á eðli veruleikans og peirri hugmynd varpað fram að hjartað feli í sér pann skilning að veruleikinn sé leyndardómur. Loks verður spurt hvaða pýðingu pað hefur fyrir hugmyndir okkar um siðferðilegan skilning og siðferðilega menntun ef hjartað er tekið alvarlega.
\end{abstract}

Efnisorð: Hjartað, berskjöldun, ímyndunaraflið, leyndardómur, menntun.

\section{Inngangur: Hvað merkir hjartað?}

Á undanförnum árum og áratugum hefur mikið verið ritað og rætt frá sjónarhóli ýmissa vísindagreina og fræðasviða um eðli tilfinninga og pátt peirra í vitundar- og félagslífi mannfólksins (Scarantino og de Sousa, 2018). Detta á ekki síst við í heimspeki, en líflegar siðfræðilegar umræður hafa meðal annars verið meðal heimspekinga um tengsl tilfinninga við dygðir og farsælt líf (Kristján Kristjánsson, 2018). Í pessum nútíma umræðum um tilfinningar skýtur af og til upp kollinum gamalt hugtak sem getur virst stinga nokkuð í stúf, líkt og forngripur í módernísku húsi. Dað er hugtakið hjarta. Orðið sjálft virðist bera með sér vissan andblæ, jafnvel einhvers konar ljóðrænu, sem greinir pað frá „tæknilegri“ orðum sem fræðimenn keppast við аð skilgreina og ræða í peirri viðleitni sinni að reyna að skilja tilfinningalíf manneskjunnar. Раð gæti pví hvarflað að athugulum lesanda að spyrja: Hvað er átt við pegar talað er um hjartað? Ekki einberan vöðvann sem dælir blóði um líkamann, heldur pað hjarta sem bregður ekki aðeins fyrir í fræðiritum heldur kemur gjarnan við sögu í trúarritum og bókmenntaverkum, og jafnframt má finna mörg dæmi um í daglegu máli.

Markmið pessarar greinar er að rannsaka nokkrar eigindir hjartans, ef svo má að orði komast, og kanna um leið hvort pessi gamla orðanotkun eigi enn eitthvert erindi í siðfræðilega orðræðu nútímans. Hér er um heimspekilega rannsókn að ræða sem pýðir meðal annars að einkum er leitað í hugmyndasmiðju heimspekinga er láta sig hjartað varða eða varpa með einhverju 
móti ljósi á merkingu hugtaksins. Sökum pess hve viðamikið viðfangsefnið er verður í raun aðeins fjallað um fáeina pætti pess, sem ætlað er að sýna fram á mikilvægi pess og hvers vegna pað verðskuldar meiri athygli en pað hlýtur oftast nær í heimspekilegri og annarri fræðilegri umræðu. Fyrst verður stuttlega vikið að pætti hjartans í sögu heimspekinnar. Pá verður fjallað um hjartað sem pá tegund skilningsgáfu sem gerir okkur kleift að bera skynbragð á eigið gildi hlutanna. Dessu næst verður rætt um pá hugmynd að hjartað sé kjarni mennskunnar vegna pess аð pað sé samtvinnað mannlegri berskjöldun og særanleika, og um leið hæfileikanum til að verða fyrir djúpum áhrifum af veruleikanum. Í framhaldinu er rætt um hjartað sem ímyndunarafl, pað er sem mátt til að sjá pað sem er, og um tengsl hjartans við pann skilning að veruleikinn sé leyndardómur. Að lokum verður reynt að draga saman fáein atriði sem sýna hvers vegna pað er mikilvægt að gæeta að hjartanu sérstaklega, og hverju pað breytir fyrir hugmyndir okkar um mennsku okkar og siðferðilega menntun að taka hugtakið alvarlega.

\section{Á hjartað heima í heimspekilegri umræou?}

Ef til vill er rétt að hefja pessa umfjöllun á pví að rekja tvenns konar mótbárur við pví að ræða yfirhöfuð um hjartað í fræðilegu samhengi. Einhverjir kynnu að halda pví fram að tal um „hjartað“ sé úrelt orðanotkun, leifar frá liðinni tíð pegar fólk tengdi sálargáfur við tiltekin líffæri, og hjartað nánar til tekið við tilfinningarnar og tilfinningalífið. Á tímum upplýstra vísinda og fræða sé betra að sleppa orðalagi af pessu tagi og ræða pess í stað einfaldlega um tilfinningar. Aðrir gætu bent á að hjartað hafi aldrei verið fyrirferðarmikið umfjöllunarefni í heimspeki eða öðrum greinum. Fá ef nokkur höfuðrit heimspekisögunnar fjalli um hjartað, hvað pá að pau séu helguð pví. Heimspekingar hafi lengst af fremur einbeitt sér að hugtökum á borð við „,hugsun“, „,kynnsemi“, „vilji“, „,öngun“ og „,kenndir“ og svo framvegis. „Hjartað“ tilheyri ekki hugtakaheimi heimspekinnar eða annarra fræðigreina - nema vitaskuld pegar sjálfur hjartavöðvinn á í hlut.

Баð er vissulega rétt að orðræða um hjartað er sprottin úr menningu og heimsmynd löngu liðinna alda, eins og glöggt má merkja af fornum trúarritum og bókmenntaverkum. Í Biblíunni er hjartans til dæmis margoft getið og sýnir pað ágæta rit raunar vel hve saga og merking orðsins er margslungin. Dar er hjartað meðal annars tengt skilningi og visku, eins og má merkja af nítugasta Davíðssálmi: „Kenn oss að telja daga vora, að vér megum öðlast viturt hjarta.“ Pá tengist hjartað sjón og skynjun, eins og pegar Páll postuli biður Guð að „upplýsa sjón hjartans“ (Efesusbréfið 1:18) eða pegar hann harmar ,,kkynlaust hjarta“ mannanna (Rómverjabréfið 1:21). Hjartað er par líka nokkuð sem getur ýmist verið hart eða mjúkt: við getum haft hjarta úr steini eða hjarta úr holdi (Esekíel 36:27), allt eftir pví hvort við erum skynug eða skynlaus á aðrar manneskjur og á guðdóminn. Jafnframt getur hjarta manna í Biblíunni verið snortið með ýmsum hætti, jafnvel svo mjög að pað brennur (Lúkasarguðspjall 24:32). Og svona mætti lengi áfram telja. Orð eru á hinn bóginn ekki sjálfkrafa úrelt pótt pau séu gömul. Eins og ég mun reyna að sýna hér á eftir hefur orðið hjarta sérstaka merkingu sem við höfum enn ríka pörf fyrir að vísa til pegar við reynum að koma hugsunum okkar um veruleikann og okkar eigin reynslu í orð. Sú staðreynd að hjartað er lifandi orð í umræðu fólks á ýmsum sviðum mannlífsins er raunar góð vísbending um аð pað svari djúpri mannlegri pörf. Fólk parfá pví að halda að ræða um pað sem er pví hjartfólgið og höfða til eigin hjarta og annarra í orðum og gerðum.

Í fljótu bragði virðist hjartað hljóta litla athygli í höfuðritum vestrænnar heimspeki. Par er pó ekki allt sem sýnist. Í pví sambandi má benda á tvö lykilverk í sögu heimspekinnar, Játningar heilags Ágústínusar og Hugsanir Pascals. Í fyrra verkinu (Ágústínus, 2006) er hjartað og samband pess við guðdóminn meginpema og hið síðara geymir meðal annars hina kunnu umræðu Pascals í pá veru að hjartað eigi sér rök sem rökhugsunin pekki ekki (Pascal, 1968, bls. 154). Bæði pessi verk, og sú umfjöllun sem par er að finna um hjartað, hafa haft mótandi áhrif á hugmyndasöguna fram á pennan dag. Enn fremur má færa fyrir pví rök að pótt sjálft orðið hjarta hafi ekki verið notað mikið af heimspekingum gegnum tíðina pá séu ýmsir af peim eiginleikum hjartans sem gerðir eru að umræðuefni í pessari grein nátengdir sögu og uppruna heimspekinnar. Að pessu 
sinni verður að nægja að nefna eitt atriði pessu til stuðnings. Eins og ég mun víkja betur að á eftir er einn peirra eiginleika sem tengjast hjartanu sá hæfileiki hinnar hugsandi, vitandi veru að geta orðið snortin eða gagntekin af veruleikanum. Dessi eiginleiki gegnir jafnframt stóru hlutverki í sögu heimspekinnar. Sem dæmi um petta má nefna eftirfarandi klausu úr Um fegurðina eftir Plótínos, par sem heimspekingurinn lýsir pví pegar sálin rekst á sanna og undursamlega fegurð:

En peir hljóta að vera til sem sjá pessa fegurð með pví sem sálin sér pvílíka hluti, og við að sjá hana gleðjast peir og eru snortnir og eru langtum meira gagnteknir en af peirri fegurð sem við ræddum fyrr ... Öll fegurð hlýtur að vekja með manni pessar geðshræringar: undrun og ljúft felmtur, löngun, ástríðu og unaðsfullt uppnám (Platon, 1999, bls. 159).

Hér má með góðum rökum halda pví fram að umræðuefni heimspekingsins sé, auk fegurðarinnar, hjartað, pað er máttur mannssálarinnar til að nema, taka á móti og verða fyrir djúpum áhrifum af hinu fagra - jafnvel pótt orðið sjálft beri ekki á góma. Okkur er mögulegt að nema hið fagra og finna til geðshræringar gagnvart pví vegna pess að við erum gædd hjarta sem getur orðið djúpt snortið og gagntekið, fullt löngunar, felmturs, ástríðu og uppnáms í snertingu sinni við raunveruleika hins fagra. Hjartað hefur hér ekki einungis merkinguna „huglæg kennd“ sem parf ekki að vera í neinum tengslum við ytri raunveruleika. Hjartað er pvert á móti orð yfir kjarna pess í mannssálinni sem Dietrich von Hildebrand kallar í bók sinni um hjartað svið geðhrifanna (e. the affective sphere), og gerir okkur kleift að bregðast við og „hrærast með“ hinum ytri veruleika (von Hildebrand, 2007).

Í pessum skilningi er hjartað ekki skýrt aðgreint frá sálargáfum á borð við sjón eða skynsemi, sem báðar gera okkur kleift að komast í snertingu við heiminn, hvor með sínum hætti. Hjartað er fremur einhvers konar kjarni skynjunar og skynsemi. Í pessari grein er pað að minnsta kosti notað yfir pann hluta okkar sem kemur okkur í nánustu og dýpstu tengslin við nokkuð sem er til utan okkar sjálfra. Ég er pví ekki fyllilega sammála Robert E. Wood, sem segir að pað sé hjartað, ekki skynsemin eða rökhugsunin, sem sé uppspretta heimspekinnar (Wood, 2015, bls. 13). Раð parf ekki að tefla ólíkum sálargáfum á móti hjartanu, pær eru í raun ólíkar birtingarmyndir pess dýrmæta eiginleika manneskjunnar að geta verið opin fyrir veruleikanum. Pað er á hinn bóginn ekki síður mikilvægt að átta sig á að ábending Roberts Wood er í aðalatriðum rétt: Hjartað er hjarta heimspekinnar, ef svo má að orði komast. Heimspeki er prátt fyrir allt viskuást - prá mannshjartans eftir visku; eftir pví að komast í tæri við og verða gagntekið af pví sem er fagurt, satt og gott. Vel má vera að heimspekingum nútímans finnist mörgum heppilegra að tengja heimspeki við skynsamlega rökræðu eða greiningu, hlutlæga gagnrýni eða afbyggingu og svo framvegis. Heimspekingar munu á hinn bóginn alltaf sitja uppi með pað að nafn peirra eigin iðju - fílósófía - er til merkis um pað að heimspeki er í grunninn knúin áfram af hjartanu; af ást, vináttu og prá eftir snertingu við pað sem er „raunverulega raunverulegt“", svo notað sé orðalag frá Iris Murdoch (Murdoch, 1997, bls. 454). Við höfum pá jafnframt eina góđa vísbendingu um pað hvers við færum á mis ef við hefðum ekki hjarta, eða ef við afneitum pví. Án mannshjartans er engin viskuást - engin eiginleg heimspeki - og að líkindum enginn skáldskapur og engin trú heldur. Hvað sem pví líður er óhætt að segja að hjartað fari með stærra hlutverk í eðli og sögu heimspekinnar en yfirborðsleg skoðun gæti fengið okkur til að ætla.

\section{Hjartað sem næmi á óviðjafnanlegt gildi}

Sé hjartað forsenda pess að veruleikinn geti snortið okkur og gagntekið pá pýðir pað um leið að hjartað er forsenda pess að við getum fyllilega metið gildi hlutanna. Í bók sinni um hjartað orðar von Hildebrand petta svo: „Fúsleikinn til að leyfa okkur að „vera hrærð“ er órjúfanlega tengdur proskuðu og djúpu skynbragði á viss gildi. Á pví leikur enginn vafi að sú næmni og hreinskilni hjartans sem er forsenda pess að „,vera hrærður“ er líka ómissandi fyrir proskað og djúpt skynbragð á siðferðileg gildi“ (2007, bls. 10). Вað sem von Hildebrand á við með „,iðferðileg gildi“ í pessu samhengi er gildi hlutarins sem slíks, pað sem hefur verið íslenskað sem eigingildi (Mikael M. Karlsson, 1994). Hjartað gerir okkur kleift að nema og bregðast við pví sjálfstæða gildi sem 
hlutirnir hafa. Degar pað pjónar sínu hlutverki „pá er pað innra mikilvægi pess sem er gott sem eitt vekur viðbrögð okkar og áhuga; við opnum okkur fyrir gildinu, fyrir pví sem er mikilvægt í sjálfu sér" (von Hildebrand, 2007, bls. 37).

Sé pað rétt að svo náin tengsl séu milli hins „,snortna hjarta“ og næmninnar á sjálfstætt gildi hlutanna er ekki að undra pótt fólk reyni að marka tali sínu um slík gildi sérstöðu. Við tölum á annan hátt um pað sem er okkur hjartfólgið en um aðra hluti. Við reynum pá ef til vill að sýna fram á mikilvægi pess sem stendur hjarta okkur nærri með pví að segja að pað hafi einstakt og óviðjafnanlegt gildi. Ágætt dæmi um petta er að finna í riti Immanuels Kant, Grundvöllur að frumspeki siðlegrar breytni, pegar Kant markar siðalögmálinu sérstöðu með ýmsu móti, meðal annars með pví að tala um ,skilyrðislaust og óviðjafnanlegt gildi“ pess og um óviðjafnanlega göfgi skynsemisvera sem setja sér slíkt lögmál (Kant, 2003, bls. 434, 436. Í niðurlagi Gagnrýni verklegrar skynsemi segir Kant enn fremur, eins og frægt er orðið, að stirndur himinninn yfir höfði okkar og siðalögmálið í brjósti okkar sé pað tvennt sem fylli hugann af sínýrri og vaxandi aðdáun og óttablandinni lotningu pví meira sem við íhugum pað (Kant, 1999, bls. 269). Við purfum ekki að gleypa siðfræðikenningu Kants með húð og hári til að geta skilið hvað hann er að fara. Við purfum einungis að lifa í tengslum við nokkuð sem við skynjum í hjarta okkar að hefur einstakt mikilvægi. Vafalaust eru pað oftast aðrar manneskjur sem við unnum eða tengjumst vináttuböndum. Баð er, hið óviðjafnanlega birtist okkur oftast í mynd annarra persóna. Hið einstaka og óviðjafnanlega birtist okkur pó einnig í ýmsum öðrum myndum. Í greininni „It All Turns on Affection“ ræðir Wendell Berry til dæmis um pað hvernig ástúð og umhyggja fólks fyrir tilteknum stað getur fengið pað til að vilja varðveita hann, tilheyra honum og dvelja á honum. Samkvæmt Berry sjáum við pá staðinn í ímyndunarafli okkar „uppljómaðan af sínum eigin einstaka karakter og af ást okkar á honum“ (Berry, 2012). Við sjáum staðinn pá sem óviðjafnanlega dýrmæta eða heilaga jörð. Listir geta líka opnað augu okkar fyrir pví sem hefur sjálfstætt og einstakt gildi. Athyglisvert dæmi um pað hvernig tónlistin, og fegurðin sem hún birtir, getur orkað á ungan huga er að finna í sjálfsævisögu Tryggva Jónssonar frá Húsafelli, Árblik og aftanskin, frá árinu 1946. Tryggvi segir frá pví pegar hann er sendur barnungur að næsta bæ, Kalmanstungu, og lýsir komu sinni pangað meðal annars svo:

Degar ég átti skammt ófarið heim að bænum heyrði ég einhvern undarlegan hljóm, - og varð mér hálf-bilt við. Hvað gat petta verið? Ég varð hálfsmeykur, - stóð parna lengi hlustandi, og var bæði hræddur og hrifinn. Að lokum pagnaði pessi hljómur, og pá áræddi ég að halda áfram, heim. Degar heim kom á hlaðið, pá stóð Ólafur par. Ég mun hafa heilsað honum, en var mikið niðri fyrir. Og svo styn ég upp einhverri tilraun til að skýra frá pessum undarlegu hljómum, sem ég skildi ekkert í, en höfðu fengið svo mjög á mig og gjört mig svona undarlega hræddan og hrifinn. - Ólafur hló dátt, tók fast í öxlina á mér, hristi mig og sneri mér í hring og mælti: „Mikill dæmalaus auli ert pú nú, Tryggvi minn. Auðvitað var petta ég - og var að spila á harmoniku.“ - „Harmoniku? Hvað er pað?““ spurði ég. - „,Рað skal ég nú sýna pér, karl minn, - og komdu nú inn!“Við göngum inn, og hann kemur með petta dularfulla galdratæki. Svo fer hann að spila, - en ég sit hljóđur og hugfanginn. Ó, - hvað pað var dásamlegt. Ég horfði á með undrun og aðdáun, hvernig hann teygði petta söngtól sundur og saman (Tryggvi Jónsson, 1946, bls. 24-25).

Orð pessa fátæka íslenska alpýðumanns lýsa pví einkar vel hvernig mannshjartað, sá eiginleiki að geta numið, hrifist og kennt í brjósti, lýkst fyrirvaralaust upp og opinberar ómælda fegurð í heiminum. Raunar er merkilega margt skylt með pessari lýsingu á upplifun sveitapilts í Borgarfirði á seinni hluta 19. aldar af pví að heyra leikið á harmóníku í fyrsta sinn og heimspekilegri útleggingu hins nýplatónska Plótínosar á 3. öld á peirri reynslu að nema sanna fegurð. Hjartað birtist hér sem sú tegund mannlegrar skilningsgáfu sem gerir okkur kleift að nema í undrun og ótta fegurðarvídd veruleikans. Рað er með öðrum orðum ekki hjartað sem eignar heiminum fegurðina - fegurðin býr ekki bara í auga sjáandans - heldur gerir pað okkur fært að nema hana 1 heiminum. Petta pýðir meðal annars, eins og ég mun víkja betur að á eftir, að hjartanu fylgir heil heimsmynd, ef svo má að orði komast. 


\section{Hjartað og særanleikinn}

Degar hjartað er tekið alvarlega sem heimspekilegt og siðfræðilegt hugtak fylgir pví ekki einvörðungu sérstök heimsmynd heldur einnig sérstakur mannskilningur. Heimspekingar hafa frá fyrstu tíð lagt áherslu á skynsemiseðli manneskjunnar og frelsi, eins og Immanuel Kant er gott dæmi um. Að ná proska sem skynsamleg vera er að ráđa lífi sínu sjálfur, vera sjálfstæður, vera ekki á valdi duttlungafullra tilfinninga, almenningsálits, illa ígrundaðra skoðana og svo framvegis. Slíkur mannskilningur er óneitanlega aðlaðandi. Hver vill ekki, ef hann íhugar rád sitt, hafa stjórn á lífi sínu fremur en lúta duttlungum annarra eða vera á valdi annarlegra sjónarmiða og afla? Hver vill ekki vera sjálfstæður? Dað er erfitt að sjá að nokkur geti vísvitandi viljað vera ósjálfráđa og ósjálfstæður. Heimspekingar hafa að vísu löngum verið meðvitaðir um að við mannfólkið erum hellisbúar - svo vísað sé til frægrar goðsagnar Platons í Ríkinu - sem í raun kjósa iðulega að lifa í myrkrinu fremur en vísvitandi og upplýstu lífi. Heimspekingarnir hafa á hinn bóginn alltaf getað vísað til pess að proskaðar manneskjur leitast við að lifa sjálfstæðu og sjálfráða lífi í samræmi við skynsemiseðli sitt.

Nú vaknar á hinn bóginn sú spurning hvað verði um pessi gildi ef komist er að peirri niðurstöðu að kjarni mennskunnar sé fólginn í hjartanu? Hvað ef eftirfarandi lýsing Jeromes A. Miller á manneðlinu er rétt?:

Af cor, latneska orðinu yfir „,hjarta“ er dregið „,kjarni“ (e. „,core“). Eins og orðið er notað í andlegum hreyfingum um allan heim merkir „hjarta“ ekki eitt líffæri eða andlegan eiginleika. Dað táknar ekki tilfinningarnar til aðgreiningar frá „höfðinu“ eða skynseminni. Dað táknar sjálfan kjarna veru okkar - kjarnann sem allir hæfileikar okkar, par með talið vitsmunirnir og skynsemin, tilheyra.Við erum eitt allsherjar hjarta vegna pess að öll vera okkar eins og hún leggur sig er bundin og undir áhrifum af særanleikanum sem er kjarni okkar (Miller, 2014, bls. 56).

Miller segir hér að hjartað sé kjarni mennsku okkar og að pað sé sérstaklega fólgið í særanleika okkar og berskjöldun. Hvað gæti réttlætt slíkan mannskilning og hvað verður um mikilvægar hugsjónir á borð við skynsemi, sjálfræði og sjálfstæði ef við tökum hann trúanlegan? Рað er í sjálfu sér auðvelt að sjá hvaða sjónarmið liggja að baki peim mannskilningi sem Miller teflir hér fram. Í stuttu máli er að minnsta kosti prennt sem getur legið til grundvallar slíkri sýn á mennsku okkar. Í fyrsta lagi er pað býsna mikilvæg staðreynd um okkur að við erum líkamlegar verur og sem slík lifum við í tíma. Lífverur eru dæmdar til að heyja lífsbaráttu og pað felur meðal annars í sér að pær eru í sífelldum opnum og gagnvirkum tengslum við umhverfi sitt, og eru sífellt útsettar fyrir áföllum, árásum, sjúkdómum og sárum. Með nöturlegu orðalagi má segja að lífsbarátta lífvera sé í pví fólgin að slá pví á frest að vera étnar. Tíminn tryggir að sú barátta hlýtur alltaf að enda á einn veg. Allt sem fæðist líður fyrr eða síðar undir lok. Í peim skilningi er særanleikinn kjarni okkar sem líkamlegra vera. Í öðru lagi erum við félagslegar, stjórnmálalegar og siðferðilegar verur. Velgengni okkar og velferð, og raunar sjálf merking lífs okkar, er að verulegu leyti bundin pví samfélagi og menningu sem við tilheyrum. Gengi okkar í mannlegu samfélagi er á hinn bóginn alltaf hád óvissu. Margt getur farið úrskeiðis í samskiptum okkar. Við erum ófullkomin og breysk og purfum í sífellu á athygli, ástúð og fyrirgefningu annarra að halda. Félagslegar aðstæður okkar taka sífelldum breytingum og geta skyndilega orðið okkur óhagstæðar, við getum glatað heilsu eða vinnu, misst nána ættingja eða vini og svo framvegis. Særanleiki er óhjákvæmilegur fylgifiskur pess að við erum samfélagslegar verur. Í priðja lagi erum við vitandi verur. Раð pýðir meðal annars að við erum ekki bara særanleg heldur einnig vitandi um særanleikann, ekki aðeins dæmd til að deyja heldur meðvituð um dauðleika okkar. Að vera líkamleg vitandi vera pýðir ekki bara að við getum áttað okkur á ýmsum staðreyndum og fundið á peim skýringar sem gera okkur kleift að ná valdi yfir beim, svo dæmi sé tekið. Vit-und okkar um veruleikann er í mikilvægum skilningi einmitt pað - und eða sár. Баð sem við vitum getur haft varanleg áhrif á okkur, snortið okkur djúpt, haft ríka pýðingu fyrir okkur. Dauði ástvinar, mikilfengleiki jökuls, hryllingur helfararinnar, fegurð tónlistarinnar, böl 
eiturlyfjaheimsins, góðvild nágrannans, tign og harðneskja náttúrunnar - pað eru engin takmörk fyrir pví hvað getur snert við okkar, og pað með svo áhrifamiklum hætti að við verðum ekki alltaf söm á eftir. Detta er allt, hvað með sínum hætti, áföll eða „tráma“ sem eru eðlilegir en oft harla pungbærir fylgifiskar pess að vera líkamlegar, vitandi verur af pví tagi sem við erum. Dessi særanleiki sem fólginn er í vitundinni sjálfri er forsenda pess að hægt er að segja að mannskepnan sé merkingarvera - vera sem heyr lífsbaráttu sem miðar ekki bara að pví að lifa af, heldur ekki síður að pví að lifa góðu og merkingarríku lífi. Ef hjartað er kjarni mennskunnar pá er pað vegna pess að mikilvægasta staðreyndin um okkur er sú að við erum ávallt opin og berskjölduð, altekin og undirlögð, af veruleika sem við höfum prátt fyrir allt litla stjórn á og er að flestu leyti ofvaxinn skilningi okkar. Рað eitt að veruleikinn er annar-legur, ekki í merkingunni geigvænlegur, heldur einfaldlega í peirri merkingu að hann er ekki endilega eins og við viljum hafa hann, hann hefur sjálfstæða tilvist og fer sínar eigin leiðir, gerir okkur opin og varnarlaus.

Hvaða áhrif hefur pessi mannskilningur á von okkar um að geta lifað frjálsu og sjálfstæðu lífi? Hjartað eins og pví er hér lýst virðist vera bæði veikt og ósjálfbjarga. Er betta ekki mannsskilningur sem upphefur pá mynd af manneskjunni að hún sé óvirkur polandi í tilverunni en gerir lítið úr getu hennar til að taka frjálsar ákvarðanir og velja sína eigin leið í lífinu? Ef hjartað ræður för, er pá ekki eins og allt annað en við sjálf ráði? Eigum við pá bara að sætta okkur við að vera á valdi annarlegs veruleika sem stendur á sama um frelsi okkar og hamingju og leikur sér að viðkvæmni okkar og áhrifagirni?

Við purfum sem betur fer ekki að svara slíkum spurningum játandi. Ef hjartað er kjarni mennskunnar pá minnir pað okkur vissulega á að í bakgrunni tilveru okkar er sú staðreynd að við erum polandi og líðandi verur. Lífið er að stórum hluta pað sem hendir okkur, drífur á daga okkar. Fæðing, vöxtur og proski, ást og dauði eru atburðir eða atburðarásir sem við göngum í gegnum. Раð pýðir á hinn bóginn ekki að við séum eingöngu óvirkir polendur. Að viðurkenna hjartað og par með særanleikann sem kjarna mannlegs lífs krefst pess ekki að maður afneiti frjálsum vilja. Баð pýðir aðeins að við áttum okkur á pví hver upphafsstaða okkar sem frjálsra gerenda er, ef svo má að orði komast. Frelsi okkar er ekki fólgið í algerlega sjálfsprottnum mætti sem ekkert hefur með berskjaldað hjarta okkar að gera. Dvert á móti er frelsið háð peirri næmni á veröldina sem berskjöldun okkar gerir mögulega. Til að skýra petta nánar er aftur gagnlegt að vitna til umræðu Jeromes Miller. Hann bendir á að upprunaleg merking sagnarinnar að pjást (e. to suffer) hafi ekki eingöngu verið að pola (e. to undergo) heldur einnig að leyfa (e. to allow). Hið sama gildi um orðið ástríða (e. passion). Ástríður á borð við ást, undrun og lotningu eru „óvirkar“ í peim skilningi að pað er eitthvað utan okkar sem vekur pær, pær eru eitthvað sem „stríðir á okkur“", og við getum pví ekki kallað pær fram pegar okkur hentar. ${ }^{1}$ Par með er pó ekki öll sagan sögð:

Við erum virk í óvirkni okkar að svo miklu leyti sem við látum okkur verða fyrir áhrifum: við opnum okkur fyrir, tökum að gefa okkur að, pví sem hreyfir við okkur ... Að breyta af heilum hug er að helga sig algerlega pví sem maður ann, að gefa sig að pví án fyrirvara, tregðu, heftingar. Innblásinn fiðluleikari gefur sig tónlistinni algerlega á vald og dregur ekkert af sér; ákafur göngumaður tekur hömlulausan eldmóð barnsins með sér í gönguna. Đótt pað sé áhrifamáttur tónlistarinnar og uppljómuð dýrð fjallastígsins í morgunskímunni sem blæs okkur í brjóst fúsleika til að helga peim krafta okkar pá veltur allt á vilja okkar til að gefa okkur peim. Petta er hin furðulega pversögn: Ástríðufullt líf felur í sér að við játumst pví sem hrærir okkur í okkar dýpsta særanleika (Miller, 2014, bls. 57).

Með pessari hugmynd um pað í hverju frjáls virkni okkar er fólgin er ekki reynt að sneiða hjá eða breiða yfir særanleika okkar heldur er pvert á móti litið á hann sem órjúfanlegan hluta, og

Colin Wilson (2009) er dæmi um höfund sem setur fyrirvara við fullyrðingu af pessu tagi. Að hans dómi getum við pjálfað okkur í að sjá heiminn með ferskum augum undrunar og lotningar. 
raunar sem meginforsendu, frelsisins. ${ }^{2}$ Án hjartans gætum við ekki verið frjáls pví án pess myndi ekkert hreyfa við okkur eða „stríða á okkur“ og við gætum pví ekki helgað líf okkar einu umfram annað eða svarað einni köllun og látið annað liggja milli hluta. Dví fer á hinn bóginn fjarri að hjartað sé par með óskeikult eða pað gefi okkur alltaf skýr svör um pað hvað sé rétt að gera. Eins og við erum margoft minnt á í hinni helgu bók pá getur hjartað verið bæði spillt og illt. Reynslan sýnir að við heillumst auðveldlega af vafasömum hlutum eða verðum hugfangin af röngum málstað. Slíkur skeikulleiki er raunar páttur í berskjöldun okkar. Eitt meginviðfangsefni ólíkra menningarsamfélaga, segir Wendell Berry (2012), hefur af pessum sökum frá upphafi verið að tempra hjartað og leiðbeina pví svo við lærum að unna pví sem vert er; hinu sanna, réttláta og fagra. Við purfum með öðrum orðum á að halda allri peirri hjálp sem við getum fengið til að tempra hjarta okkar og beina ástríðum pess í réttar áttir; við purfum til dæmis lærdóm fyrri kynslóða og reynslu og skynsemi peirra sem eldri eru. Dað dugar pó ekki til nema við getum um leið stuðst við viskuna sem leynist í okkar eigin hjarta.

Ég hef hér tengt hjartað við pann skilning að kjarni manneskjunnar sé fólginn í særanleika hennar sem líkamlegrar, félagslegrar og vitandi veru; við ,sérstakan skilning á hinu mennska dýri sem getur hlotið sár og verið ásótt af pví sem er"- svo notuð séu orð Stephen Mulhall í bók hans The wounded animal (2009, bls. 73). Hjartað hefur pví bæði líkamlegri og heildrænni skírskotun, ef svo má segja, en annars góð og gild hugtök á borð við skynsemi eða hugsun. Í pví að vísa til hjartans í máli sínu felst meðal annars að draga sérstaklega fram pá staðreynd að við erum ekki bara hugsandi verur heldur líkamlegar hugsandi verur, eining líkama, sálar og hugsunar. Dað vísar til pess að kynni manneskjunnar af veruleikanum geta svo gagntekið líkama og sál, orðið svo nákominn hluti af holdi hennar og blóði, að sjálf vera hennar titri eins og slaghörpustrengur eða henni blæði eins og úr opinni und. Skilningur manns í slíkum tilfellum er beinlínis líkamlegur eða „holdgaður“ (Coetzee, 1999). Um leið er hjartað ekki með sama hætti og skynsemishugtakið tengt peirri hugmynd að við eigum ávallt að reyna að vera við stjórnvölinn, pað er að hefja okkur yfir eða ná stjórn á særanleika okkar. Skynsemi, sjálfræði og sjálfsstjórn eru allt mikilvæg gildi en ofuráhersla á pau getur fengið okkur til að bæla pann frumpátt mennskunnar sem gerir okkur í sífellu opin og móttækileg fyrir pví sem er annað en við sjálf og við höfum ekki stjórn á.

\section{Hjartað og ímyndunaraflið}

Eins og áđur var minnst á tengist hjartað frá fornu fari bæði visku og skynjun. Í fornri semískri menningu Miðausturlanda var til dæmis ekki litið á hjartað fyrst og fremst sem aðsetur tilfinninga eða kennda heldur sem skynfæri (O’Connor, 2015, bls. 162). Hjartað er pá einhvers konar innra auga eða eyra - innsæi - sem við purfum á að halda til að átta okkur og kunna að meta hlutina að verðleikum. Af pví fjölmarga sem vert væri að segja um petta staldra ég við eitt atriði; pátt ímyndunaraflsins í pessari innri skynjun hjartans.

Wendell Berry og Iris Murdoch eru meðal peirra heimspekinga sem leggja sérstaka áherslu á ímyndunaraflið sem eins konar innra skynfæri. Berry segir að ímyndunaraflið sé hæfileiki okkar til að „sjá í ítrasta skýrleika, kunnugleika og skilningi með augunum, en einnig að sjá hið innra, með „,auga hugans“. Баð er að sjá ekki sem óvirkur áhorfandi heldur með mætti opinberunarinnar" (Berry, 2012). Að dómi Murdoch, á hinn bóginn, erum við mannfólkið að verulegu leyti blind á veröldina, og pað sem blindar okkur er einkum sjálfið með allri sinni práhyggju, kvíða, öfund, gremju og ótta. Hvert og eitt okkar hneigist til að búa sér til lítinn persónulegan heim sjálfsins sem einangrar okkur frá umheiminum (Murdoch, 1997, bls. 14). Við lifum að stórum hluta í heimi draumóra (e. fantasy). Рað sem getur á hinn bóginn, að minnsta kosti stöku sinnum, opnað pennan draumóraheim upp á gátt og komið okkur í snertingu við raunveruleikann er ímyndunaraflið: „Ímyndunaraflið, gagnstætt við draumórana, er hæfileikinn til að sjá pað sem er annað en maður sjálfur" (Murdoch, 1997, bls. 255). Dað er hæfileiki okkar til að veita heiminum og pví sem í honum er raunverulega athygli.

рað parf ef til vill ekki að benda á að pessi hugsjón um hið ástríðufulla líf getur vakið tortryggni peirra sem leggja punga áherslu á sjálfrææi. Immanuel Kant er hér aftur ágæt viðmiðun. Írski heimspekingurinn William Desmond minnist á pað í einni bóka sinna að Kant hafi á sínum tíma búið í nágrenni við fangelsi par sem fangarnir voru látnir syngja sálma, hinum mikla hugsuði til sárrar skapraunar. Dessi reynsla hafi gert Kant svo tortrygginn gagnvart mætti tónlistarinnar til að snerta okkur gegn vilja okkar að hann hafi í riti sínu Gagnrýni dómgreindarinnar lagst gegn ,söng andlegra sálma“ á peim forsendum að slíkur söngur neyði nágrannana annaðhvort til að syngja með eða láta af hugleiðingum sínum (Desmond, 2008, bls. 96n). 
Mér virðist eðlilegt að tengja pá sjóngáfu ímyndunaraflsins sem Berry og Murdoch ræða um peirri ævagömlu hugmynd að hjartað sé einhvers konar (innri) skynjun. Рað sem rennir stoðum undir slíka tengingu er til dæmis að ímyndunaraflið er, samkvæmt Murdoch, náskylt ástinni. Hún segir meðal annars að ástin sé viðurkenning prungin ímyndunarafli (e. imaginative recognition) á tilvist eða „,annar-leika“ annars fólks: „Ást er skynjun á einstaklingum. Ást er sú gríðarlega erfiða viðurkenning að eitthvað annað en maður sjálfur er raunverulegt. Ást, og par með listir og siðferði, er uppgötvun veruleikans“ (Murdoch, 1997, bls. 215). Sú „skynjun“ eða „sjón“ sem Murdoch hefur í huga pegar hún ræðir um ímyndunaraflið og ástina er pví að ýmsu leyti sérstök. Nefna má prennt í pessu sambandi. Í fyrsta lagi gerir ímyndunaraflið með einhverjum hætti sýnilegt pað sem er pegar sýnilegt og fyrir framan nefið á okkur alla daga, án pess að við berum fyllilega kennsl á pað - annað fólk, náttúruna, heiminn. Ímyndunaraflið felur pess vegna í sér einhvers konar vakningu, eins og við séum að sjá eitthvað í fyrsta sinn, rétt eins og heimurinn sé skyndilega orðinn nýr og hafi öðlast endurnýjað aðdráttarafl. Í öđru lagi er slík skynjun ekki siðferðilega hlutlaus. Hún felur pvert á móti í sér siðferðilegan skilning á gildi pess sem við skynjum. Við sjáum sjálfstæða tilvist annarra í ljósi „hins góđa“, eins og Murdoch talar gjarnan um. Í priðja lagi er skynjun ímyndunaraflsins nátengd sérstökum skilningi á heiminum. Ímyndunaraflið gefur okkur með öðrum orðum sérstaka sýn á heiminn, pað opnar augu okkar fyrir annarri afstöðu til veruleikans í heild en við erum vön. Í pessum anda segir Murdoch í greininni „Sýn og val í siðferði“ að ágreiningur fólks í siðferðilegum efnum spretti ekki aðeins af pví að pað velur ólíka hluti í saman heiminum heldur af pví að pad sér ólíka heima (Murdoch, 1997, bls. 82). Heimurinn sem við sjáum með ímyndunaraflinu er annar en heimurinn sem við sjáum í draumórakenndri vökuvitund okkar. Afstaða okkar til pess hvaða heimi við tilheyrum er í grundvallaratriðum önnur.

Til að útskýra petta síðasta atriði aðeins nánar má ef til vill nota dæmi sem ættað er úr smiðju G. K. Chesterton, en par reynir hann að koma orðum að grundvallarlífssýn sinni:

Að baki öllu lífi okkar er ómæli ljóss sem er skærara og ómælanlegra en nokkurt hyldýpi myrkurs; og pað er ómæli raunveruleikans, tilvistarinnar, peirrar staðreyndar að hlutirnir eru í raun og sannleika, og að við sjálf erum ótrúlega og stundum nánast óskiljanlega raunveruleg. Detta er grunnstaðreynd verunnar, öndvert pví sem ekki er; veran er óhugsandi og samt getum við ekki afhugsað hana, pótt við séum oft hugsunarlaus um hana; laus við hugsun og sérstaklega laus við pakkir. Dví sá sem hefur borið kennsl á pennan veruleika veit að hann vegur bókstaflega óendanlega miklu pyngra en öll minni háttar eftirsjá eða rök fyrir aðfinnslum, og að undir öllu okkar nöldri býr ómeðvituð uppspretta pakklætis (Chesterton, 1931, bls. 36).

Dað er augljóst að Chesterton er hér að lýsa afstöđu til veruleikans í heild; hann er að tala um sérstaka sýn á raunveruleikann, tilvistina, pá staðreynd að eitthvað er til yfirhöfuð. Um leið er hann að lýsa pví hvað pað pýðir að bera kennsl á eða sjá pennan veruleika. Að sjá veruleikann er аð hans dómi andstæða pess að vera hugsunarlaus um hann, taka honum sem sjálfsögðum hlut, eða öllu heldur að sjá hann sem nánast óskiljanlegt undur; sem gjöf fremur en eitthvað gefið. Eins og Murdoch telur Chesterton að slík sýn á heiminn komi sjaldnast af sjálfu sér, að minnsta kosti ekki hjá fullorðnu fólki, og að hún krefjist ögunar og ástundunar af vissu tagi. Hún er undir pví komin að við getum virkjað hjartað í formi ímyndunaraflsins, pví pað er ímyndunaraflið sem getur dregið fram og gert lifandi fyrir okkur pann bakgrunn mannlífsins sem flestir ganga einfaldlega að sem gefnum, án pess að gefa pví nokkurn gaum, sem er tilvistin sjálf. Um leið er раð hjartað sem gerir okkur kleift að verða snortin af pessari almennustu „eigind“ alls með peim hætti að við finnum til pakklatis andspænis henni. Chesterton heldur pví fram að pað form sem hugsunin tekur á sig andspænis tilvistinni sé pakklæti. Dótt Chesterton og Martin Heidegger séu býsna ólíkir hugsuðir pá mætist hugsun peirra hvað petta varðar. Heidegger ræðir pann möguleika í Was Heisst Denken? að hugsunin sé náskyld pakklætinu. Hann gerir sér í pví sambandi mat úr orðsifjalegum skyldleika sagnanna að penkja og pakka (p. denken, danken; e. think, thank). Heidegger spyr meðal annars hvort hugsun sé pakkargjörð: „Væri pá æðsta 
pakklætið hugsun? Og dýpsta vanpakklætið hugsunarleysi? ... Hreint pakklæti er fremur pað að við einfaldlega hugsum - hugsum pað sem er raunverulega og algerlega gefið, pað sem kallar á hugsun“" (Heidegger, 1968, bls. 143).

Hér gefst ekki færi á að ræða nánar um tengsl hugsunar um tilvistina og pakklætis. Mér virðast orð Chestertons á hinn bóginn vera gott dæmi um pað hvernig hjartað, í mynd ímyndunaraflsins, getur opnað augu okkar og sýn, ekki aðeins á einstök fyrirbæri eða ferla náttúrunnar heldur á veruleikann í heild sinni, pá makalausu staðreynd að pað er eitthvað til yfirleitt og að við erum „ótrúlega og stundum nánast óskiljanlega raunveruleg“. Í næsta kafla skoðum við pá veruleikasýn sem hér um ræðir ofurlítið nánar.

\section{Hjartað og leyndardómurinn}

Рað sem áður var sagt um tengsl hjartans við sýn á og afstöðu til veruleikans í heild leiðir að atriði sem einhverjir myndu vafalaust draga í efa að tengist umfjöllunarefni okkar yfir höfuð, pótt mér virðist öll umræða um hjartað purfa að taka pað með í reikninginn: Fyrir hjartanu er veruleikinn leyndardómur. Nú gætu margir sagt að peir hafi ekki hugmynd um hvað petta pýðir nema hvað pað geti varla verið neitt gott. Við erum öll börn Upplýsingarinnar og okkur er pess vegna í blóð borið að tortryggja allt tal um leyndardóma, dularfull og yfirnáttúruleg fyrirbæri, drauga, kraftaverk og svo framvegis. Samt er pað svo að ef við skoðun nánar hvað pað pýðir að hafa hjarta og hugsa með hjartanu pá komumst við fljótlega að peirri niðurstöðu að heimurinn sem við tilheyrum sé leyndardómur, í peim skilningi að hann er prunginn meiri veruleika, gildi og merkingu en við getum með góðu móti áttað okkur á. Petta pýðir að hjartanu fylgir viss frumspeki, pað er afstaða til veruleikans sem ekki er endilega sú sem við sem búum á Vesturlöndum snemma á tuttugustu og fyrstu öld höfum vanist, eða orðið samdauna eins og fiskar vatni. ${ }^{3}$

Til að glöggva sig á hvað pað pýðir að líta á heiminn sem leyndardóm má byrja á að skoða snöggvast hvað pað pýðir að gera pað ekki, úr pví að margt bendir til að sú afstaða sé víðast hvar sjálfgefin nú á dögum. Mikið hefur verið ritað um pað hvernig veruleikasýn vestræns nútímafólks einkennist af afhelgun (Taylor, 2007). Afhelgun getur pýtt margt en í grófum dráttum er hún tengd við hugmyndastrauma sem ná undirtökum á vesturlöndum á nýöld. Einn peirra sem hvað oftast er nefndur í tengslum við pessa hugmyndastrauma er franski heimspekingurinn René Descartes. Í ritum Descartes birtist náttúran í grunninn sem vél sem hægt er að skilja með táknmáli stærðfræðinnar og hið efnislega er fyrst og fremst skilið sem mælanlegt rúmtak (Descartes 1998, 2001). ${ }^{4}$ Slíkar hugmyndir eiga pátt 1 a a greiða veg peirri afstöðu sem hefur smám saman orðið ráđandi að náttúran hafi enga merkingu eða gildi sem slík. Öll merking komi einungis frá hinni hugsandi veru, við ljáum náttúrunni merkingu og gildi í huga okkar. Afhelgun merkir að svona pekkjum við nútímafólk heiminn upp til hópa, að minnsta kosti pegar við erum í hlutverkum okkar sem stjórnmálafólk, athafnaskáld, vísindamenn, tæknikratar, fjármagnseigendur, neytendur og svo framvegis. Við hneigjumst til að tengja pekkingu á heiminum fyrst og fremst við hið stærðfræðilega og mælanlega en merkingu og gildi við okkar eigin huga.

Sumir hafa orðað pessa afstöðu til náttúrunnar á pá leið að hún geri ráð fyrir að heimurinn og allt sem í honum er sé ,gildislaust parna“ (Desmond, 2008). Lífsviðhorf af pessu tagi vekur ýmsar áhugaverðar spurningar sem vert væri að ræða. Gengur pað upp sem sjálfri sér samkvæm lífsafstaða? Hvernig er hægt að meta hvort pað er sannleikanum samkvæmt? Er petta farsæll grunnur fyrir pað siðferði sem mannkynið parf að temja sér gagnvart náttúrunni til framtíðar? Hér verður pó aðeins bent á að afstaða af pessu tagi samræmist illa rökvísi hjartans.Við höfum séð að hjartað er sá kjarni mennskunnar sem er opinn fyrir eigingildi fyrirbæranna, pví sjálfstæða mikilvægi sem hlutirnir hafa. Dað er aðsetur pess hæfileika okkar að geta verið í snertingu við og snortin af pví sem er annað en við sjálf. Við getum sagt að hjartað geri okkur á-stríðufull, pað er pað gerir okkur fær um að hrærast og hrífast pegar veruleikinn stríðir á okkur. Dað gerir okkur pess vegna líka mögulegt að fyllast raunverulegum á-huga, pað er að sýna fyrirbærum pessa

\footnotetext{
James R. Peters (2009) fjallar um tengsl skynsemi og hjarta við ólíkar frumspekilegar hugmyndir í The Logic of the Heart; Augustine, Pascal and the Rationality of Faith.

Sjá gagnrýni Páls Skúlasonar (2014) á heimsmynd Descartes í „Hugleiðingar við Öskju“.
} 
heims og annars djúpa og undrunarfulla athygli. Dað er á hinn bóginn erfitt að sjá hvernig hægt er að hafa sannan áhuga á „gildislausu parna“. Eini „,áhuginn“ sem slíkt fyrirbæri virðist geta vakið beinist að mögulegu notagildi pess fyrir verur eins og okkur. Раð er erfitt að verjast peirri hugsun að slík afhelgun heimsins sé til merkis um ,rýrnun“ hjartans og um leið mennskunnar (von Hildebrand, 2012, bls. 55). Slík rýrnun hjartans skerðir ekki aðeins möguleika okkar til að lifa góðu lífi í samfélagi við aðra menn heldur kemur einnig í veg fyrir að við metum fyrirbæri

náttúrunnar að verðleikum. Í vistkreppu nútímans er ástæða til að ætla að við purfum sem aldrei fyrr á pví að halda að geta orðið snortin af veruleika okkar, veitt fyrirbærunum og eigingildi peirra hugulsama og undrunarfulla athygli - og kunnað um leið að njóta peirra sem slíkra.Við purfum pá að reyna að temja okkur pá afstöđu að hvert einasta fyrirbæri sé ekki bara brot af óendanlegri mergð hlutanna heldur eins og heill heimur út af fyrir sig og verðskuldi sem slíkt fulla aðgát okkar og lotningu.

Að segja að veruleikinn sé leyndardómur er að viðurkenna að hann er flóknari og margslungnari en hægt er að skilja með góðu móti, pað er að kannast við að bókstaflega allt er prungið dýpri merkingu og gildi en við getum áttað okkur gjörla á. Heimurinn er ekki bara parna kaldur og hlutlaus í rúmtaki sínu og stærðfræðilegum eigindum - sem raunvísindin munu smám saman ná að skýra til fulls. Líf okkar er ekki bara merkingarlaus próunarfræðileg hending, pótt hendingar séu vissulega sláandi páttur í lífi okkar allra. Að pekkja náttúruna í raun og veru er með öðrum orðum að pekkja hana ekki bara sem keðju orsaka og afleiðinga eða merkingarsnautt hráefni. Баð er miklu fremur að pekkja hana sem leyndardóm sem er gegnsýrður af og ofinn saman úr merkingu og gildum hins sanna, fagra og góða; pess sem heimspekingar fornaldar og miðalda litu gjarnan á sem innstu patti veruleikans, pað sem á enskri tungu er kallað the transcendentals (Schmitz, 2007). Frá pessum sjónarhóli er náttúran voldug voð par sem orka, frumefni, efnasambönd, lífverur og vistkerfi eru ofin saman í eina órofa heild meðan frumpræðirnir, veran, sannleikurinn, fegurðin og gæskan, halda henni saman. Ég veit að slíkt orðalag kemur mörgum spánskt fyrir sjónir nú á dögum, en pað er pó að minnsta kosti viðleitni til að koma í orð pví grundvallarinnsæi hjarta okkar að heimurinn og verurnar sem par er af finna eru meira undur en orð fá með góðu móti fangað.

\section{Hjartað, mennskan og siðferðileg menntun}

Að lokum er vert að varpa fram peirri spurningu hvaða pýðingu pað hjartahugtak sem hér hefur verið til umræðu hefur fyrir hugmyndir okkar um menntun, einkum siðferðilega menntun; menntun sem varðar með einhverjum hætti spurninguna „hvernig lífi er best að lifa?“ Hafa parf í huga pegar pessi spurning er borin upp að tæpast er um neitt mótað fræðilegt viðfangsefni að ræða, hvað pá fræðasvið, sem fjallar um „menntun hjartans“. Kristján Kristjánsson (2018, bls. 184) bendir raunar á pað í nýlegri bók sinni að hið sama gildi um viðfangsefnið „,menntun tilfinninganna“ - fræðileg skrif um pað viðfangsefni séu samtíningslegur bútasaumur sem sárlega parfnist nánari rannsókna, greiningar og yfirvegunar. Peim premur atriðum sem hér verða nefnd er pví fyrst og fremst ætlað að vekja hugboð um раð hvaða pýðingu mann- og veruleikaskilningur hjartans gæti haft fyrir hugmyndir okkar um siðferðilega menntun. Dessi atriði tengjast öll peirri grundvallarhugmynd að siðferðileg menntun varði með einhverjum hætti pað viðvarandi verkefni að vekja og proska skilning hjartans andspænis verum og gildum pessa heims. Hún sé viðleitni til að komast til fullrar vitundar um pá berskjölduðu mennsku sem við öll deilum og vinna um leið gegn peirri mjög svo mannlegu tilhneigingu okkar að pykjast vera eitthvað annað og meira en takmarkaðar og særanlegar manneskjur.

Siðferðileg menntun er pá í fyrsta lagi ferli sem miðar að viðurkenningu á og sátt við mannlegar takmarkanir og særanleika í ólíkum myndum. Með nokkrum rétti mætti kannski segja að flestar ef ekki allar greinar mannlegra fræða, og listir og trúarbrögð einnig, stuðli með einhverjum hætti að siðferðilegri menntun í pessum skilningi. Deim er með ýmsum hætti ætlað að nálgast og miðla með öguðum aðferðum einhverjum sannindum eða sjálfstæðum veruleika. Ég vek pó sérstaka 
athygli á heimspekinni og aðferðum hennar í pessu sambandi pví hún er sú vídd mannlegrar tilveru par sem viðurkenning mannlegra takmarkana og særanleika verður hvað mest knýjandi. Detta birtist hvað skýrast hjá heimspekingnum Sókratesi sem, eins og Marina Berzins McCoy bendir á í bók sinni um dygð særanleikans, er sífellt að hvetja til sérstakrar aðgátar gagnvart „takmörkum eigin mennsku“, og brýna menn til að bregðast við peim af ábyrgð (2013, bls. 136). Sókrates er meðal annars kunnur fyrir að hafa haldið pví fram að peir sem iðki heimspeki með réttum hætti temji sér pað eitt að deyja og vera dauðir (Platon, 1996, bls. 109), og fyrir að hafa sagt að hann hefði komist til peirrar viðurkenningar að pekking sín væri einskis virði (Platon, 1996, bls. 40). Hvort tveggja ber glöggt vitni vitund um eigin takmarkanir, og um takmarkanir mennskunnar yfirleitt. Раð er fátt jafn auðmýkjandi og að standa frammi fyrir dauða sínum eða viðurkenna stórkostlega vanpekkingu sína frammi fyrir öðrum, pað er að játa að maður hafi engin almennileg tök hvorki á lífinu né sannleikanum. Fáir eiga auðvelt með að horfast í augu og bregðast með uppbyggilegum hætti við slíkum staðreyndum um sjálfa sig. Að ástunda heimspeki er viðleitni til að hrökkva ekki undan peim heldur gera pær að grunnpætti hinnar heimspekilegu leitar. Ef pað аð spyrja heimspekilegrar spurningar felur í raun í sér meðvitund um að maður sé gjörsamlega villtur, eins og Jerome Miller bendir á (1992, bls. 3), pá varðar pað líka sjálfan kjarna peirrar heimspekihefðar sem rakin er til Sókratesar að viðurkenna að maður hefur tapað áttum og veit ekki hvert á að halda (Lear, 2001). Бað er að viðurkenna að maður sé í sárri pörf fyrir góða leiðbeinendur og samræðufélaga sem geta hjálpað manni að bera kennsl á takmarkanir sínar og leita um leið að pví sem hefur raunverulegt gildi.

Heimspekin er vitaskuld aðeins ein peirra leiða sem hægt er að feta 1 átt að viðurkenningu á mannlegum takmörkunum og særanleika. Dess má geta í pessu sambandi að bandaríski félagsráðgjafinn Brene Brown hefur fjallað á athyglisverðan hátt um mikilvægi pess að pora að gera pað sem gerir mann berskjaldaðan og hafa dug til að varpa fyrir róða lönguninni til að vera alltaf með allt á hreinu, hafa stjórn á öllum hlutum (Brown, 2012). Hún hefur líka fjallað um margt í okkur sjálfum og menningu okkar sem stuðlar að hinu gagnstæða með pví til dæmis að læða pví í sífellu að fólki að pað að berskjalda sig sé pað versta sem maður gerir. Petta eru pættir eins og fullkomnunarárátta, ofuráhersla á samkeppni og árangur, ótti við álit annarra, ótti við аð verða að athlægi, skömm og svo framvegis. Siðferðileg menntun sem miðaði fyrst og fremst að sátt okkar við mennskuna myndi hjálpa okkur að viðurkenna slíka hegðun og átta okkur á pví hve ógagnleg hún er sem viðbrögð við eðlilegum takmörkunum mannlegs lífs. Í pessu sambandi er vert að nefna eina tegund af andlegri vinnu með öðru fólki sem hefur pað beinlínis að markmiði að hjálpa okkur að viðurkenna eigin vanmátt, en pað er starf í anda tólf sporanna.

Í öðru lagi snýst siðferðileg menntun til sáttar við mennskuna um pá grundvallarviðurkenningu аð við erum ekki miðja alheimsins, að aðrir eru alveg jafn raunverulegir og við sjálf og að við erum öll hluti af heild og samfélagi. Iris Murdoch orðar pessa hugsun svo að dygðin sé í pví fólgin að skilja að aðrir eru til (1997, bls. 284). Detta hljómar undarlega sem lýsing á dygð ef maður gefur sér að slíkur skilningur sé öllum í blóð borinn eða komi af sjálfu sér. Er dygð ekki nokkuð sem krefst uppeldis, aga og ræktunar? Raunin er á hinn bóginn sú að pað er fátt sem veitist okkur eins erfitt og að skilja til hlítar að líf annarra, gleði og sorgir, ást, sársauki og missir, er alveg jafn raunverulegt og kallar á alveg jafn mikla umhyggju og athygli og okkar eigið líf. Við höfum alls konar leiðir til að telja sjálfum okkur trú um að líf annarra vegi með einhverjum hætti ekki eins pungt og okkar eigið (Gaita, 2002). Sönn menntun miðar að pví að hjálpa manneskjunni að finna pann kyrra og hljóðláta stað innra með sjálfri sér par sem hún getur hlýtt með óskiptri athygli á sjálfstæða tilvist annarra, ef svo má að orði komast. Siðferðileg menntun hlýtur með öðrum orðum að purfa að fela í sér hugleiðandi pátt, pað er viðleitni til að proska skyn, skilning og yfirvegun gagnvart peim leyndardómi sem tilvist annarra er. Í pessu sambandi er vert að benda á skrif bandaríska heimspekingsins Coru Diamond (1991), en hún hefur bent sérstaklega á pað hvernig undrunarfullur skilningur á mannlegu lífi sem sameiginlegu og leyndardómsfullu ferðalagi frá vöggu til grafar getur mótað hugsanir fólks, orð og gerðir og dýpkað samstöðu pess, samúð og mildi. 
Í beinu framhaldi af pessu myndi menntun hjartans, menntun til upprifjunar mennskunnar,

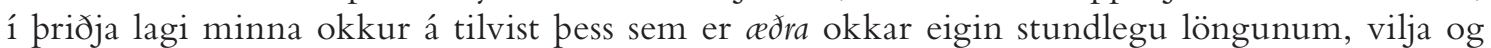
hagsmunum, pess sem kallar á virðingu okkar og lotningu vegna pess að pað er meira, fegurra og dýrmætara en við fáum með góðu móti skilið (Woodruff, 2001). Detta æðra getur verið af ýmsu tagi: Fyrir læknakandídatinum getur pað verið sjúklingurinn eða sjálf læknislistin, fyrir kennaranum nemandinn og proski hans, fyrir stjórnmálamanninum almenningur og hugsjónin um réttlátara og frjálsara samfélag og svo framvegis. Samkvæmt pessari sýn er sambandið við hið æðra - einhvern grundvallarveruleika, gildi eða hugsjón - aflvaki allrar siðferðilegrar menntunar, og við ættum ekki að vera feimin við að viðurkenna að svo sé. Sönn menntun felur með öðrum orðum ævinlega í sér viðurkenningu okkar á og berskjöldun okkur gagnvart æðri mælikvörðum; sérhver hugsjón er eins og sjálfstæður dómari sem dæmir líf okkar og verk. Fátt gerir okkur berskjaldaðri og um leið mennskari en að lifa í tengslum við slíka mælikvarða.

Sjálfur álít ég að mikilvægi hins æðra í mannlegu lífi geri pað að verkum að siðferðileg menntun sé á endanum nátengd pví að rækta sambandið við hið guðlega. Mér er nær að halda að ef guðdómurinn væri ekki til pyrfti mannfólkið að finna hann upp, pótt ekki væri nema í peim tilgangi аð pað geti minnt sig á mennsku sína og ræktað hana - orðið fyllilega mennskt. Аð verða mennskur er að læra að opna skynfæri sín og huga - alla sálina - gagnvart pví sem er ekki maður sjálfur, pví sem maður hefur ekki skapað og er ekki á manns valdi, pví sem hefur til að bera fegurð og dýrmæti hvað sem líður manns eigin hagsmunum og ráðagerðum. Við sköpuðum ekki veruleikann, við sköpuðum ekki fegurðina eða hið góða, við sköpuðum ekki einu sinni okkar eigin hæfileika. Slíka hluti er sannast og skynsamlegast að líta á sem ómetanlegar gjafir sem okkur eru færðar. Ef til vill er pað besta við að vera ekki guð að pá getur maður tekið glaður og pakklátur á móti slíkum gjöfum og forðast um leið pann hvimleiða sið sumra guðanna að taka sjálfa sig of hátíðlega. Hér erum við pá í lokin komin að spurningunni um forsendur sjálfrar lífshamingju okkar mannanna og hvernig pær tengist pví að líta ekki of stórt á sig, belgja sig ekki út. Еða eins og Chesterton orðar pað: Englarnir geta flogið vegna pess að peir taka sjálfa sig létt.

\section{Niðurlag}

Í pessari grein hefur verið leitast við að varpa ljósi á hjartað, hugtak sem víða bregður fyrir í máli fólks, hvort sem er í daglegu tali, bókmennum eða fræðilegri orðræðu, en fær sjaldan pá skipulegu umfjöllun sem pað verðskuldar. Færð hafa verið rök fyrir pví að við purfum á hugtakinu að halda, meðal annars vegna pess að pað tengist mikilvægum mann- og veruleikaskilningi sem á enn pann dag í dag brýnt erindi við fólk. Að ræða blátt áfram um „hjartað sanna og góða“, fremur en til dæmis um tilfinningar, felur samkvæmt pví sem hér hefur verið haldið fram í sér pá grundvallarviðurkenningu að heimurinn og líf okkar í honum er leyndardómur. Um leið er hjartað orð sem dregur sérstaklega fram pá staðreynd að við erum líkamlegar, skynjandi, hugsandi sálir, í náinni snertingu við aðrar slíkar sálir og við veröldina í heild. Í pví menningarlega andrúmslofti sundrungar sem færa má rök fyrir að sé hlutskipti okkar nú um stundir (Schindler, 2017) purfum við á orðum og hugtökum að halda sem minna okkur á náin tengsl, ef ekki einingu, anda og efnis, sálar og líkama, skynsemi og tilfinninga. Umfram allt minnir hjartað okkur pó á að við erum fyrst og fremst hverfular, líkamlegar, vitandi verur, í senn berskjölduð fyrir sjálfstæðum veruleikanum og opin fyrir pví undri sem hann er. 


\section{The Heart; the Core of Humanity and Education?}

This article is an attempt to elucidate, as well as celebrate, the notion of the heart. Although poets, songwriters and others appeal to the heart all the time, philosophical treatises on the heart are rare. Yet I claim that philosophers, even those who emphasize the supreme role of reason, appeal to the heart. Indeed, the heart is at "the heart" of philosophy itself since the word literally means love of wisdom. There are, therefore, few topics that are more proper for philosophical examination, and yet also few that are more vast and elusive. I thus limit my discussion on the heart to five themes that are by no means meant to be exhaustive. Firstly, I examine what Dietrich von Hildebrand describes as an objective "value-response" of "the true affective experience". The heart is, in other words, a faculty of appreciation which makes us sensible to objective worth. Wonder, reverence and a sense of beauty, for example, are all responses of the heart that can reveal to us some important aspect or dimension of reality. This implies, among other things, that to take the heart seriously is to take serious note of the idea that meaning and value is not only an aspect of the human mind but also a feature of reality our minds can receive. Secondly, I explore the connections between the heart and human vulnerability. Here I take my lead from the philosopher Jerome Miller who has demonstrated in his writings how the vulnerability at the core of our lives is what defines us as human beings, for better and for worse. It is our vulnerability and openness to "the other", to people, beings and to reality as such which constantly makes us liable to be profoundly touched by things beyond our control. On the other hand, this exposure also makes us eager to gain power over our lives and the pursuit of control can easily become an obsession which makes us forget the vulnerability at the heart of life. It is in any case important for our wellbeing and the wellbeing of our society that we learn to temper our hearts and expose them to the right things and in the right measure. Thirdly, I discuss the link between the heart and the imagination. Here I draw on thinkers like Wendell Berry, G.K. Chesterton and Iris Murdoch who understand the imagination not as the source of fantasies but an ability to see things clearly and passionately. The imagination is a power of the heart to recover and enliven the knowledge we already have of the reality of others and the wonder and strangeness of being. Fourthly, I argue that talking about the heart does not make full sense unless we acknowledge reality as a mystery. By this I mean that to know things in one's heart is to be aware of their aspects and dimensions that one can never fully comprehend - not only regarding their physical nature and interrelations to other things, but also with respect to their origin, existence, meaning, beauty, goodness, and so forth. Lastly, I consider what difference it makes for our understanding of moral education if we take these ideas about the heart seriously. I claim (a) that education would help us grow in and thorough our heart's vulnerability. I hold (b) that education would primarily be a process whereby we learn to acknowledge truly the reality of the lives of others and the existence of things. And I maintain (c) that to acknowledge the centrality of the heart means that education has once again become a way for human beings to travel towards and live by something greater than themselves.

Key words: The Heart, Inherent Value, Vulnerability, Imagination, Mystery, Education. 


\section{Um höfundinn}

Jón Ásgeir Kalmansson (jonkalma@hi.is) er aðjúnkt við Menntavísindasvið Háskóla Íslands.

\section{About the author}

Jón Ásgeir Kalmansson (jonkalma@hi.is) is an adjunct at the University of Iceland, School of Education.

\section{Heimildir}

Ágústínus. (2006). Játningar (Sigurbjörn Einarsson pýddi). Reykjavík: Hið íslenzka bókmenntafélag.

Berry, W. (2012). It all turns on affection. The Jefferson lecture and other essays. Berkeley: Counterpoint.

Brown, B. (2012). Daring greatly: How the courage to be vulnerable transforms the way we live, love, parent, and lead. Toronto: Penguin Books.

Chesterton, G. K. (1931). Chaucer. London: Faber \& Faber.

Coetzee, J. M. (1999). The lives of animals. Princeton: Princeton University Press.

Descartes, R. (1998). Orðræðа um aðferð (Magnús G. Jónsson pýddi). Reykjavík: Hið íslenzka bókmenntafélag.

Descartes, R. (2001). Hugleiðingar um frumspeki (Dorsteinn Gylfason pýddi). Reykjavík: Hið íslenzka bókmenntafélag.

Desmond, W. (2008). God and the between. Oxford: Blackwell Publishing.

Diamond, C. (1991). The importance of being human. Í David Cockburn (ritstjóri), Being human, bls. 35-62. New York: The Press Syndicate of the University of Cambridge.

Gaita, R. (2002). A common humanity. London: Routledge.

Heidegger, M. (1968). What is called thinking? (J. Glenn Gray pýddi). New York: Harper Colophon Books.

Kant, I. (1999). Critique of practical reason (Mary J. Gregor pýddi). Í Mary J. Gregor (ritstjóri), Practical philosophy, bls. 133-270. Cambridge: Cambridge University Press.

Kant, I. (2003). Grundvöllur að frumspeki siðlegrar breytni (Guðmundur Heiðar Frímannsson pýddi). Reykjavík: Hið íslenzka bókmenntafélag.

Kristján Kristjánsson. (2018). Virtuous emotions. Oxford: Oxford University Press.

Lear, L. (2001). A case for irony. Cambridge: Harvard University Press.

McCoy, M. B. (2013). Wounded heroes. Vulnerability as a virtue in ancient Greek literature and philosophy. Oxford: Oxford University Press.

Mikael M. Karlsson. (1994). Náttúran sem skepna. Í Róbert H. Haraldsson og Porvarður Árnason (ritstjórar), Náttúrusýn. Safn greina um siðfræði og náttúru, bls. 91-101. Reykjavík: Siðfræðistofnun.

Miller, J. A. (1992). In the throe of wonder. Intimations of the sacred in a post-modern world. New York: State University of New York Press.

Miller,J.A. (2014). Sobering wisdom: Philosophical explorations of twelve step spirituality. Charlottesville: University of Virginia Press.

Mulhall, S. (2009). The wounded animal. J. M. Coutzee and the difficulty of reality in literature and philosophy. Princeton: Princeton University Press.

Murdoch, I. (1997). Existentialists and mystics. New York: Penguin Books.

O'Connor, D. K. (2015). Plato's bedroom. Ancient wisdom and modern love. South Bend, Indiana: St. Augustine's Press.

Pascal, B. (1968). Pensées (A. J. Krailsheimer býddi). Baltimore: Penguin Books.

Páll Skúlason. (2014). Náttúrupælingar. Reykjavík: Háskólaútgáfan.

Peters, J. R. (2009). The logic of the heart. Augustine, Pascal, and the rationality of faith. Grand Rapids: Baker Academic. 
Platon. 1996. Síðustu dagar Sókratesar (Sigurður Nordal og Porsteinn Gylfason pýddu). Reykjavík: Hið íslenzka bókmenntafélag.

Platon. (1999). Samdrykkjan (Eyjólfur Kjalar Emilsson pýddi). Reykjavík: Hið íslenzka bókmenntafélag.

Scarantino, A. og de Sousa, R. (2018). Emotion. Í Edward N. Zalta (ritstjóri), The Stanford encyclopedia of philosophy. Sótt af https://plato.stanford.edu/archives/win2018/entries/emotion/

Schindler, D. C. (2017). Freedom from reality. The diabolical character of modern liberty. Notre Dame: University of Notre Dame Press.

Schmitz, K. L. (2007). The texture of being. Essays in first philosophy. Washington: The Catholic University.

von Hildebrand, D. (2007). The heart:An analysis of human and divine affectivity. South Bend: St. Augustine's Press.

Taylor, C. (2007). The secular age. Cambridge:The Belknap Press of Harvard University Press.

Tryggvi Jónsson. (1946). Árblik og aftanskin. Akureyri: Norðri.

Wilson, C. (2009). Super-consciousness. The quest for the peak experience. London: Watkins Publishing.

Wood, R. E. (2015). The beautiful, the true and the good: Studies in the history of thought. Washington, D.C.:The Catholic University Press.

Woodruff, P. (2001). Reverence. Renewing a forgotten virtue. Oxford: Oxford University Press.

Jón Ásgeir Kalmansson. (2018).

Hjartað, kjarni mennsku og menntunar?

Netla - veftímarit um uppeldi og menntun. Sérrit 2018 - Menntakvika 2018. Menntavísindasvið Háskóla Íslands.

Sótt af http://netla.hi.is/serrit/2018/menntakvika_2018/01.pdf

DOI: https://doi.org/10.24270/serritnetla.2019.25 